\title{
Theater Without a Script- Improvisation and the Experimental Stage of the Early Mid-Twentieth Century in the United States
}

\section{ABSTRACT}

It was in the mid-twentieth century that the independent theatrical form based entirely on improvisation, known now as improvisational/ improvised theatre, impro or improv, came into existence and took shape. Viola Spolin, the intellectual and the logician behind the improvisational movement, first used her improvised games as a WPA worker running theater classes for underprivileged youth in Chicago in 1939. But it was not until 1955 that her son, Paul Sills, together with a college theater group, the Compass Players, used Spolin's games on stage. In the 1970s Sills made the format famous with his other project, the Second City.

Since the emergence of improv in the US coincides with the renaissance of improvisation in theater, in this paper, I will look back at what may have prepared and propelled the emergence of improvised theater in the United States. Hence, this article is an attempt to look at the use of improvisation in theater and performing arts in the United States in the second half of the $20^{\text {th }}$ century in order to highlight the various roles and functions of improvisation in the experimental theater of the day by analyzing how some of the most influential experimental theaters used improvisation as a means of play development, a component of actor training and an important element of the rehearsal process.

Keywords: theatre, impro(v), experimental theater, improvisation. 
"Improvised performance is as old as performance itself" (Sharma 46), and even Viola Spolin, the High Priestess of Improvised Theatre, points to its different traditions: “Improvisation isn't new, for god's sakes. The commedia dell'arte improvised. The socialist political theatres in Europe improvised. They didn't read it anywhere. They were working on what was happening in the streets" (qtd. in Coleman 26).

Spolin started creating her "theater games" in 1939 when she commenced her work as a drama supervisor for the Works Progress Administration's Recreational Project in Chicago, teaching "creative dramatics to ghetto children from the West Side streets" (Coleman 23). By then the theater had undergone what is referred to as The Great Reform and was still in the midst of an experimental phase that embraced many robust historical avant-garde theater movements. In such an atmosphere of experimentation and change, sundry movements were coming to life and new ideas were materializing, encouraging writers and artists to take bold steps and to try unconventional, novel approaches towards art.

In the early 1960s, when Spolin was teaching improv games in Chicago to her son's improv company The Second City, Keith Johnstone was building up his improvisational system while training actors at the Royal Court Theatre Studio in London. In the introduction to Impro for Storytellers, Johnstone states that he had no knowledge of any other improvisation at the time (xii). Notwithstanding, as early as the 1950s, the young American comedian Dudley Riggs would tour the country with his vaudevillian act, which encompassed "acrobatics, juggling, and improvisational comedy" (Regan). He would refer to this as "word jazz" since the troupe musicians "were adamant that the word improvisation belonged to jazz" (Regan). As noted in Sharma's Comedy in New Light, "some people credit American Dudley Riggs as the first vaudevillian to use audience suggestions to create improvised sketches" (46). Yet, according to Coleman, "this hallmark technique of the modern improvisational theater" (30) was first used by Spolin in 1936.

In this paper, I will examine the use of improvisation in theater and performing arts in the United States in the second half of the $20^{\text {th }}$ century, prior and parallel to the emergence of what is now known as impro, improv, improvisational or improvised theater. ${ }^{1}$ By analyzing how

1 The terms improvisational theater, improvised theater and impro(v) are used interchangeably throughout the paper. I, however, make a distinction between impro and improv, as explained in the article "Alchemy and Smoke in a Bottle-Contemporary Improvisational Theater in Poland and the United States" published in Acta Universitatis Lodziensis: Folia Litteraria Polonica 2.40 (2017). 
various American companies and artists from the 1950s to the 1970s used improvisation, I will highlight its many uses, functions and roles in the development of the American stage, both avant-garde and popular, which in turn might have given way to an independent theatrical formatimpro(v).

\section{The Second Reform of the Theater ${ }^{2}$ and the American Avant-Garde. American Theater Comes into its Own}

The Second Reform of the Theater was a natural continuation of the Great Reform. Having lasted approximately four decades, from the 1950 s up to the 1990s, it was far from uniform. Its gradual development, however, was synchronous in Europe and the United States. In this study, I will focus on the first phase of the Reform (1950-75), since during this period improvisation as a technique of acting and means of creation was central to the development of the new theater. The Living Theatre, Grotowski's Laboratory, Kantor's Cricot 2 Theater, Happenings, Actions and Events, the emergence of Off- and Off-Off-Broadway theaters and Schumanns's Bread and Puppet Theater are some of the key figures and groups of the movement. Yet again, although diverse in styles and methodologies, they had shared ideologies. They were open (towards both fellow company members and audiences), rebellious (towards the ingrained status quo of arts in general, and of theater in particular, as well as opposing the ideals of a consumer society), anti-war, political, socially engaged, transcendental in nature and defiant of structure and tradition. The new theater supported social equality, multiculturalism and the individual right to freedom-of speech, actions and views. They also engaged in spatial experimentation in the spirit of Grotowski's exit from the theater, seeking new venues to perform in in order to be closer to the people. In the US this primarily meant moving away from Broadway:

They wanted to change the world but had to change the theater first. In the first phase, it was a collective product, a process of artistic interaction between actors, director, musicians, and stage designers through improvisation.... The "openness" and audience participation was crucial. (Braun 314, translation mine)

2 The Second Reform of the Theater is a term coined by Kazimierz Braun. As the term is widely quoted in the Polish theater studies, I will use it throughout the paper when referring to the experimental and avant-garde theater movements of the second half of the $20^{\text {th }}$ century. 
The negation of traditional theater, both politically and artistically, together with the theatralization of other arts (John Cage's and Allan Kaprov's happenings, Jackson Pollocks's action painting), significantly altered and reshaped the definition of theater. The experiments at the beginning of the $20^{\text {th }}$ century stretched the boundaries of theater, making room for more experimentation and alteration, which in turn paved the way in the second half of the century for new theatrical forms, such as Happenings, Events, Actions, and impro(v).

The American stage provided fertile ground for these changes. Lacking a centuries-long theater tradition while possessing the necessary infrastructure and human resources, as well as the burgeoning ideologies planted a few decades before, the artists in the US had a more than favorable environment for experimentation. James Roose-Evans wrote in 1970 that "the greatest variety of experimentation in the theatre today is to be found in America" (144). By the 1950s, the universities had already trained actors, playwrights, critics and technical staff, as well as informed, knowledgeable and well-educated audience. The ideas of the European emigrants coalesced with American heritage to form a new American drama and theater. Many critics, Franck Jotterand among them, claim that the history of American theater begins in 1916 with the staging of Eugene O'Neill's Bound East for Cardiff (9). Debatable as this statement is, this national playwright certainly had a major influence on the shaping of the American stage. Indigenous characters, familiar events, colloquial language and the use of idiolects in his plays have contributed to the development of a truly American drama, both formally and conceptually. Political events have also greatly marked drama and theater in the United States. The Great Depression of the 1930s that questioned existing values, the HUAC atmosphere of fear and suspicion in the 1940 s that intensified the need for freedom and openness in the arts, the Korean War in the 1950s and the Vietnam War in the 1960s, which overturned so many perceptions that America had about itself, engaged the theater politically to an even greater extent. The American stage, although heavily influenced by the European avantgarde, was developing autonomously.

The most noteworthy formal changes were those that took place in the style of acting, the use of written text (or lack thereof), and spatial experimentation. The "new acting," originated by Stanislavsky, was expanding and evolving and differed among the artists who took up the role of teachers, yet it always concentrated on one goal. Acting was understood as being, not pretending to be somebody else on stage. The prime idea was to find the emotions inside and reveal them instead of playing them out. This was often achieved through improvisation. The written text 
was either non-literary, or non-existent-the performances used either few words, or the words were improvised (either on the spot or during the rehearsal process). In order to escape the artificiality of theater stages the performance space moved away not only from Broadway to private apartments and specially constructed venues, but also out of any buildings. The actors performed in parks, railway stations and basements. By using a real-life space open to actual passers-by, in contrast to performing in front of a theater audience on artificial grounds, they were in medias res of particular, real situations. This improvised performance space manifested the notion of "people's theater," in which the actors could interact with an arbitrary, accidental audience.

Improvisation in theater, long before it became a separate theatrical form, was an important factor in the creation of the new theater (re) invented in the wake of an artistic search for new solutions and directions. It was a part of experimentation, of an ongoing artistic exploration. In the formal sense, it was an acting technique, and a teaching method used by Joseph Chaikin and Viola Spolin, in the so-called transformational acting "based on Brechtian alienation to enable actors to take up different roles in a sequence" (Braun 315, translation mine). Improvisation was used in space and stage design, as a part of the process of creation or even as a basic strategy of performance.

\section{The Performative Rebellion: Happening, Performance, EVENT}

In 1952 at The Black Mountain College, an experimental school in North Carolina, John Cage, together with Charles Olson, M. C. Richardson, David Tudor, Merce Cunningham, Robert Raushenberg and a group of dancers, staged Theater Piece \#1 (Black Mountain Piece), a rather odd performance, which subsequently came to be known as the first Happening, a term coined by Allan Kaprov. It has never been determined what exactly happened in The Black Mountain College that day, as according to Ross, "no two accounts agreed" (400). However, in The Rest Is Noise: Listening to the Twentieth Century he gives a vague description of the events:

Cage lectured on Zen Buddhism, perhaps standing on a ladder. Robert Rauschenberg exhibited artworks and/or played Edith Piaf records at double speed. Merce Cunningham danced. David Tudor played prepared piano. Movies of some kind were shown, boys or girls served coffee, a dog may or may not have barked. (Ross 400) 
Cage, through his experimentation, extended or crossed the boundaries of art forms, which in turn gave way to an entirely new form. The Happening and its cousins: Events, Performances and Acts bloomed in the USA in the 1950s and influenced many avant-garde artists in Europe in the 1960s (Mueller xx). They incorporated music, painting, sculpture, film and theater in an attempt to discredit the traditional forms and challenge expectations. While Environments created by the Dadaists and Surrealists were interrelated with painting and sculpture, Happenings related in the sense of composition to music and theater. For Kaprov, a Happening was an improvised collage of events, with no logical link. The goal was to awaken the senses, to recognize and rediscover the surrounding people and environment, to engage an individual and society; it was as much to expand the boundaries of the form as it was to broaden horizons, alter perspectives and ignite critical thinking. The Fluxus movement under the leadership of George Maciunas developed its "anti-art," anti-commercial aesthetics ("Fluxus, Performance, Participation"). Some of the so-called Fluxpieces, such as Milan Knížák's A Week, were to engage people in game-like activities to initiate adventures and open people to different kinds of interaction (Jotterand 96-101):

1st day-all your clothes should have same color. Also underwear.

2nd day-keep silent all day long.

3rd day-look at your naked body in a mirror for at least an hour. Do it carefully.

4 th day-

5 th day-sing or whistle the same tune all day long without a pause.

6th day-make a trip by train. Buy no ticket.

7th day — walk all day long aimlessly through the city. The best is alone.

(Knizak 65)

However, such artistic interventions soon became a channel to vent dissatisfaction with and dissent from social and political norms. Anti-war and civil rights movement happenings and performances became a widespread form of protest in America in the 1960s. They took place in the streets, at universities, and even in courtrooms. The leaders of the leftist Youth International Parties, Abbie Hoffman and Jerry Rubin, referred to the movement as guerilla theater. When called to appear before the HUAC, Hoffman and Rubin showed up for questioning in judicial robes. At other times, Rubin would also wear an Independence War uniform, a Vietcong sweatshirt and carry a toy gun, or dress up as Santa Claus. Jotterand claims that the Yippies aimed at igniting crises, surprise and sudden changes in the fossilized system of 
frames of reference (113). Words did not suffice anymore; they would not ignite immediate intervention or reaction, nor would they kindle turmoil around the most important political issues and unacceptable social norms. Happenings did.

The Happenings, the often-nonverbal political commentaries, left the art galleries and became a revolutionary means in the streets of America. In the theater, the spirit of Happening was an inspiration to discover space and new attitude towards audiences (Jotterand 118). It also showed how theater could influence public perception, inspire change, and affect individuals and societies in non-artistic dimensions.

Theater is a State of Mind: The Off-Broadway Movement AND BEYOND

Away from the expensive Broadway venues, and the highly commercial entertainment of the Great White Way, a new theater arose in the late 1940s. The Off- and Off-Off-Broadway movement first started in private apartments and basements among the new generation of artists predominantly influenced by the European avant-garde, yet, with the American tradition already carved into this influence. It was a poor, experimental avant-garde theater, small in size and budget, looking for new means of expression, promoting new drama, too complex for the popular stages of Broadway:

[Off-Broadway] grew in the succeeding decades to rival Broadway in the dynamics of its more challenging plays and productions. And it proved to be a theatre that would mould significant careers of playwrights, actors, designers, and directors in a more accessible and clearly sequential, stepby-step process of progress. (Witcover 260)

The burgeoning theater was expanding, and by 1949 there were enough theaters to establish a formal association-The League of OffBroadway Theatres. In 1975 the Off-Off-Broadway Alliance was founded (Braun 319-21). This movement strove for an entirely different kind of entertainment from what Broadway had to offer. With intellectuals and artists in mind as a target audience, Off-Broadway did not compete with The Great White Way, but was more of a highbrow alternative to the popular mass entertainment. Widely diverse in form and content, the "off companies" (see Table 1) were almost entirely unified in their vision of the mission of the new theater. Politically oriented, socially engaged Brechtian performance art and its objectives prevailed on the Off-Broadway stage. 
Theater Without a Script. The Experimental Stage in the USA

\begin{tabular}{|l|c|}
\hline Experimental theaters & established in \\
\hline The Living Theatre & 1951 \\
\hline The Bread and Puppet Theatre & 1961 \\
\hline The Open Theater & 1963 \\
\hline The San Francisco Mime Troupe & 1963 \\
\hline The Performance Group & 1967 \\
\hline The Manhattan Project & 1968 \\
\hline
\end{tabular}

Table 1. Selected experimental theaters in the 1950s-60s (see Braun).

\section{The Living Theatre-Julian Beck and Judith Malina}

The Living Theatre, an experimental group founded by Julian Beck and Judith Malina in New York, held their first performances in the Becks' Upper West Side apartment in 1947. The group performed in different venues over the course of the next three decades. Evicted in 1952 from the Cherry Lane Theater they had rented the previous year in Greenwich, "the company relocated to another nontheater space-a large loft way uptown" (Bottoms 24). Following their flight to Europe in 1963, the company would perform in even more unconventional venues, "from the prisons of Brazil to the gates of the Pittsburgh steel mills, and the slums of Palermo" ("Living Theatre Records").

In his book Playing Underground: A Critical History of the 1960s OffOff-Broadway Movement, Steven J. Bottoms recalls Malina's own words claiming that the Becks wanted to create a theater of "pure art, pure poetry, [with] the highest level of artistic adventure, the highest level of experiment, the highest level of political advance" (24). Such a mission bears clear traces of the influences of the European avant-garde. In fact, both Beck and Malina studied at the New School for Social Research in New York under Erwin Piscator, the famous precursor of political theater (Braun 322-23), where they took acting classes and learnt to theatricalize politics and to politicize theater. Jotterand also attributes their critical attitude to Brecht's influence and recalls Chaikin's words that the German playwright "would make a perfect member of The Living Theatre" (121, translation mine). Aside from the German leftist artists, Beck's inspirations derived from the aesthetics of the French dramatist, Antonin Artaud. Bigsby believes that Julian Beck, "heavily influenced by Artaud, ... sought to assault the sensibility of the audience," therefore, "following [Artaud's] prescriptions,... [he] came to reject that kind of theatre in which individuals are required to sit isolated from one another 
in the dark" (63). As a matter of fact, many critics, among them Franck Jotterand, perceived features of the theater of cruelty in the company's performances such as the famous The Brig or Frankenstein (126-27).

It appears that Beck and Malina were also well aware of contemporary American artists who used performing arts as a vessel to vent their dissatisfaction with current social and political affairs. One of these rebels was Lenny Bruce, the pioneering stand-up comedian "renowned for his open, free-style and critical form of comedy which integrated satire, politics, religion, sex, and vulgarity" ("Lenny Bruce"), a satirist who "elevated street language into an art form" (Olson 76). Bruce faced a number of arrests on the grounds of obscenity, leading to a famous trial in 1964:

Back in New York City in April, Judith and Julian attended the trial of comedian Lenny Bruce on obscenity charges, both because they felt a sense of kinship with him, and because they had decided to represent themselves in their own trial and wanted to familiarize themselves with the intricacies of court procedure. (Tytell, The Living Theatre 192)

The Becks felt they suffered from similar oppression from the authorities; however, in their case the repression was cloaked in tax evasion charges. " $[\mathrm{T}]$ he Internal Revenue Service moved to shut the theater down for tax evasion. Beck, Malina and their supporters felt they were being singled out in an act of de facto censorship" (Tytell, "Troubadours Against Oppression"). During the trial, Malina represented Beck dressed up as Portia in The Merchant of Venice (Botting 18), which seems to be a rather direct reference to the Yippies cross-dressing performances at the HUAC interrogations over a decade earlier.

The Living Theatre was as political in its art as it was experimental. The company "started off with scripted plays by new Europan and American playwrights, and landed at collective improvisation" (Jotterand 118-34, translation mine). For the first two decades they were a spearhead in the staging of poetic drama, promoting both American (Gertrude Stein, John Ashbery, Paul Goodman, William Carlos Williams) and European authors (Brecht, Cocteau, Pirandello, Lorca) rarely produced in the US at the time.

The Connection, a 1959 play by Jack Gelber, was, if not groundbreaking, certainly a milestone production for the company. The cast comprised jazz musicians, who according to Jotterand improvised as if under the influence of narcotics, while the actors remained in a state of waiting (120). The play, based on improvised music and dialogue was, apart from an artistic experiment, a close-to-anarchistic experience for the 
company. In his essay, "Storming the Barricades," Beck emphasizes this liberating dimension of The Connection for him and the company:

\begin{abstract}
We, who had sought to develop style through variations of formal staging, found suddenly in the free movement and the true improvisation of The Connection something we had not formerly considered. An atmosphere of freedom in the performance was established and encouraged, and this seemed to promote a truthfulness, startling in performance, which we had not so thoroughly produced before. (139)
\end{abstract}

In their subsequent production, The Marrying Maiden (1960), The Living Theatre continued experimenting with improvisation. In this "theatre work created by Jackson MacLow, one of Cage's students, in which characters and speeches were selected from the I-Ching" (RooseEvans 146), the lines, in terms of rhythm and intonation, were strictly determined by the score. "The order, duration of speeches, and the directions for rate, volume, inflection and manner of speaking were all independently ascribed to the material by chance techniques" (RooseEvans 146). This was achieved through the 1200 "action cards" added by Judith Malina, randomly given to the actors to perform whatever action was assigned by the card.

Other actions were inserted at random by the employment of a pack of twelve hundred cards, each one containing stage directions such as"scratch yourself," "use any three objects in an action," "kiss the nearest woman," etc. These were given to the performers, in full view of the audience by a stage manager who rolled dice in order to determine the throw of the cards (Roose-Evans, 146).

This chance factor ignited by the use of the action cards carries a striking resemblance to Viola Spolin's games. In fact, this resemblance is far from coincidental, as one of the ensemble members, Joseph Chaikin, had first-hand acquaintance of the games, having had previously worked with "the grandmother of improvisation" herself (Styan 167).

Two more noteworthy productions of The Living Theatre with inspiration heavily drawn from improvisation are Mysteries and Smaller Pieces (1964) and, perhaps the most famous theater work staged by the company, Paradise Now (1968). While the former is a collective improvisation, the first performance of The Living Theatre not based on a script by one author alone (Jotterand 122), the semi-improvised Paradise Now, based on discussions by the company members, was "a kind of improvised performance in itself . . . and a celebration of artistic work as a collaborative process" (Caines and Heble 116). Audience participation was a key element in both productions-though Cage's influence is 
stronger in Mysteries and Smaller Pieces_-induced by nothingness, silence, lack of movement, but also addressing the audience and demanding answers, and inviting active participation of the audiences in Paradise Now. Jotterand describes how actors would join the audience during intervals, "first to collect donations, then to infect them with bubonic plague, or even to drag them on stage" (129, translation mine).

\section{The Open Theater-Joseph Chaikin}

After the Becks left for Europe with the The Living Theatre ensembletaking up "voluntary exile"-the director Joseph Chaikin joined another Off-Broadway company. The Open Theater, which was established in 1963 by a group of former students of Nola Chilton in New York, comprised "writers, directors, actors, musicians, a painter and two critics" (Jotterand 139, translation mine). Although it was an entirely different artistic endeavor in many respects, the two companies shared a similar inclination towards experimentation, the exploration of social, political and artistic issues, and improvisation.

The Open Theater was a performance ensemble as much as it was an experimental lab, drawing heavily on Jerzy Grotowski's ideas and experience. The Open Theater was a workshop, where actors, directors, musicians and choreographers met. In these workshops the artists improvised dialogues and situations, which formed whole performances in the process. (Braun 320-28). Chaikin was influenced by the Polish artist, who supported the American company. According to Bigsby,

Open Theatre was the only one that Grotowski was willing to endorse, doubtless because its emphasis was on the actor, and its distrust of the substitution of a physical for a spiritual, emotional or intellectual contact with its audience was one to which he responded. (114)

The famous director and theater theorist even appeared in person at one of the company's workshops in 1967.

Chaikin greatly appreciated Grotowski's teaching methods, although he acknowledged they were different from his own (Jotterand 144-45), which he derived from the experience of many avant-garde artists, European and American. "Chaikin had trained as an actor with the Stanislavsky System, acted in Brecht's epic theatre and worked with Viola Spolin" (Styan 167). He shared Grotowski's "belief in the need of physical discipline, combined with an investigation of the nature of sound of movement" (Bigsby 114), which was an underlying motif for 
the exercises he engaged the actors in during the-again, Grotowskilike-lab rehearsals/workshops. The exercises were not detached from the artistic process; rather than separate segments, they were pieces of a bigger whole, parts of the artistic development. "Like Brecht, Chaikin thought of his theatre as a workshop where plays were always '“in progress,' always growing and changing" (Styan 167). In his words quoted by Jotterand, Chaikin claims that "exercises are worthless if, as a result, they do not engender a theatrical performance" (145, translation mine).

Chaikin also

shared both Meyerhold's belief in the need to work from the physical fact of the actor's presence on stage and his conviction that this meant exploring the mechanics of physical movement, but, more than that, he saw in the presence of the actor a statement about the power of human intervention. (Bigsby 121)

He was also no stranger to Lee Strasberg's ideas, or to the teacher himself, whom he met in New York in 1966. Yet Chaikin resented his method:

He teaches the actors to use themselves, but at the same time they withdraw into themselves because of the excessive use of autoanalysis. This defers team acting. He looks at the performance in a logical, linear way. How can you stage Brecht in such a way? (qtd. in Jotterand 137, translation mine)

By examining many avant-garde ideas, techniques and methods, Joseph Chaikin managed to devise his own combination of principles, techniques and creative explorations and create his personal artistic style. Jotterand claims that Chaikin's method is not only the key to understanding the new American theater, but that it also shows the long road that the American stage took from naturalism to abstractionism (136-40). Taking after the pioneer of socially engaged theater in Israel, Nola Chilton, and influenced by Bertold Brecht's ideas, The Open Theater's work was particularly political (anti-Vietnam war performances) in nature. However, according to Jotterand, adding humor to the performances was a distinctive American, and "non-Grotowski," feature (145).

Chaikin's adoption of improvisation was also different from what he learnt with Spolin and The Living Theatre. For The Open Theater, improvisation was a part of the process of creation rather than a basic strategy of performance (Bigsby 119). However, like some of the Spolin games and The Marrying Maiden staged by his former company, Comings and Goings, a play by Megan Terry produced by The Open Theater in 1966, was based on aleatoricism. In this production, the actors presented their 
scenes in an order determined by a roulette wheel. In later productions, such as The Serpent and Terminal, the company also experimented with group improvisation.

\section{The Performance Group-Richard Schechner}

The New American Theater was thriving when The Performance Group, a highly experimental Off-Off-Broadway company, was brought to life by Richard Schechner in 1967. "Like Chaikin's, this group was not formed primarily for the purpose of developing a production, but rather to explore theatrical and personal possibilities" (Bigsby 125).

Schechner had received an extensive (also Ivy League) education and earned a $\mathrm{PhD}$ in theater with Tulane University before starting the company. His academic research and his personal explorations orbited around experimental and avant-garde theater. "Influenced by Grotowski, whom Schechner had met in 1966, by the Becks and by the environmentalists and their Happenings" (Styan 169), he formed his own experimental company. Not unlike Chaikin, Schechner developed his own distinctive style that derived from many different sources. "Having attended a workshop with Grotowski, Richard Schechner aimed at just such precision but hardly purged his work of sentimentalism" (Bigsby 124). The early productions of The Performance Group were based on existing scripted plays with texts created by the director (Macbeth, 1969; Dionysus 69, 1968). Hinged on the William Arrowsmith translation of Euripides' The Bacchae, Dionysus in 69 was a play devised by Schechner through group improvisation. According to Braun, he would also use improvisation during rehearsals to create space and stage design (330-32) for his productions.

The company adopted a former metal stamping/flatware factory in Soho for their performance space, by visually turning it into a garage, and naming it aptly-The Performing Garage. This empty, spacious area was an ideal venue for Schechner's spatial experimentation. He "examined the spatial relations between the characters on stage, as well as between the actors and the audience to create appropriate space for those relations" (Braun 331, translation mine). Schechner's idea of "environmental theater," and its core aim, was to eliminate the physical boundaries between the actors and the audiences in order to facilitate interaction between them and create a common space, which in turn would form a collective environment for everyone engaged in the performance. The company

shaped the theatre to conform to each play, constructing different audience frameworks for each production. The sets were usually based on 
multilevel platforms, balconies, ramps, and scaffolds surrounding a stage that encroached on the audience's territory, providing a wider range of space for the actors and a greater flexibility of interaction between the audience and performers. The audience of the environmental theatre was invited, even expected, to participate. ("Environmental Theatre")

Such literal breaking of the fourth wall incorporates the ideas of Cocteau, Artaud and Brecht, and provides an underlying philosophy for artists rejecting traditional theater venues.

\section{The Bread And Puppet Theatre-Peter Schumann}

Peter Schumann brought his Bread and Puppet Theatre from Germany to New York in 1961, and was also prepared to play anywhere (Styan 166). According to Roose-Evans, the one space he rejected was that of the traditional theater (121). The theatrical work of The Bread and Puppet Theater, a politically radical performance group, revolved around protesting through the means of performing arts against contemporary social and political ills. This included Anti-Vietnam War and anti-draft protests, support for Daniel Ortega, and opposition to the World Trade Organization. The group did not have a permanent location; instead, in the spirit of environmental theater, they performed in the streets. The Bread and Puppet Theater rejected not only traditional venues and manifested dissatisfaction with the sociopolitical situation, but also renounced any forms of traditional theater. In his manifesto-like article for The Drama Review in 1968, Schumann describes the mission of his company, and the theater in general:

We give you a piece of bread with the puppet show because our bread and theater belong together. For a long time the theater arts have been separated from the stomach. Theater was entertainment. Theater is different. It is more like bread, more like a necessity. Theater is a form of religion.

Puppet theater is the theater of all means. Puppets and masks should be played in the street. They are louder than the traffic. They don't teach problems, but they scream and dance and display life in its clearest terms. Puppet theater is of action rather than dialogue. The action is reduced to the simplest dance-like and specialized gestures.

We have two types of puppet shows: good ones and bad ones, but all of them are for good and against evil. (35)

Schumann took the Brechtian principle of people's theater quite literally by bringing it to the streets of New York. His Happening-like 
performances involving 20 feet tall puppets could hardly go unnoticed. He soon succeeded in having his voice heard, even if the dialogues were marginal and scarce. Since the artistic means of the performances relied mainly upon music and movement, and involved audience participation, "Bread and Puppet's scripts were minimally written, [and] the performances more or less improvised" (Secor 268). Schumann, however, unlike Chaikin or the Becks, did not use improvisation as a rehearsal tool, or an acting method. It was more of a natural outcome resulting from the very nature of the performance-annexing the surroundings to adopt them as the performance space and converting random passers-by into an accidental audience.

\section{The Manhattan Project; Andre Gregory and the} San Francisco Mime Troupe; RG Davis

Other important experimentalists of the day that combined the ideas of the European avant-garde and contributed to the development of the new American theater were Andre Gregory and RG Davis. Gregory, before leaving for Poland to work with his former teacher, Jerzy Grotowski, led an experimental company perversely named The Manhattan Project. Having studied acting under Lee Strasberg and Sanford Meisner, he combined their acting techniques with Grotowski's principles. Hence, his production of Alice in Wonderland (1970) was devised through laboratory rehearsals based on improvisation (Braun 333).

RG Davis's experimental project, The San Francisco Mime Troupe, founded in 1959, was as far away from Broadway in terms of distance as it was in its mindset. The company began with Event-like performances based on music and visual art, but was soon experimenting with commedia dell'arte that, in part, heavily relied on improvisation. The troupe "began by playing Moliere and Goldoni in the style of the commedia dell'arte, until Davis took his productions out-of-doors as a form of street theatre" (Styan 166). Similarly to Off-Broadway productions, The Troupe's performances served as critical commentaries on contemporary events. Their adaptation of Goldoni's comedy L'amant Militaire aimed to criticize the Vietnam War. In addition, the group actively partook in organized anti-war protests by forming a marching band that encouraged the demonstrators to "unite theater and revolution and groove in the parks," for which they were awarded their first Obie Award in 1968 ("The San Francisco Mime Troupe, History"). One of the most interesting of Davis's projects subverted and put to new use a $19^{\text {th }}$-century spectacle: "In 1965, Davis, Saul Landau, and a racially mixed group of actors created 
A Minstrel Show, or Civil Rights in a Cracker Barrel, using a historically racist form to attack racism in both its redneck and liberal varieties" ("The San Francisco Mime Troupe, History"). Davis coalesced the formal and political ideas of Brecht, whose direction, according the Troupe's official website, he sought, with popular theatrical forms such as commedia dell'arte and a minstrel show and presenting them in a distinctively American context.

\section{The New Theater-From Anarchy to Impro(V)}

American artists were audacious in seeking new spheres of expression for thought and action, eagerly exploring various routes of artistic discovery and inspiration. The Reform and the European avant-garde had a lasting impact on the American theater. The ideas, principles and styles which emerged on the Old Continent found their way onto the American stage, and, by merging with distinctive American qualities and traditions, contributed greatly to the formation of the unique character of the evolving American theater.

The new theater was distinctly anarchic both in form and content. It rejected "all traditional techniques, story-line, naturalistic representation, plot, suspense, climax, denouement” (Roose-Evans 146). As such, it stood discernibly in opposition to traditional theater. In many respects, the artists also manifested their anti-government stance, which they expressed through politically and socially engaged performances, the incorporation of themes of social and racial inequality, and active participation in antiwar protests. The anarchic notion that an individual should be free of all constraints was enhanced through the choice of non-theatrical venues and the use of improvisation as a means of artistic expression. The American artists explored the wide variety of possibilities that improvisation offered them as a creative tool, a method, a component in the creative process of the performance and play development, as well as a valuable aid in actors' training. Such an inclination towards experimentation and the exploration of new styles and methods led to the emergence of various new theatrical forms.

\section{Conclusion}

This paper shows, in a very narrow yet carefully selected scope, how the American stage combined various forms and functions of improvisation and through these experiments created brand new, distinctively American 
styles and forms. Out of this concoction, through various inspirations and collective ideas, the improvisational theater was born-a separate, complex entity, "a performance product in and of itself" (Napier 1), relying purely on improvisation, not only as a means, but also as an end result.

\section{Works CiTED}

Beck, Julian. "Storming the Barricades." Anarchism: A Documentary History of Libertarian Ideas. Ed. Robert Graham. Montreal: Black Rose, 2009. Print.

Bigsby, C. W. E. A Critical Introduction to Twentieth-Century American Drama. Beyond Broadway. Volume 3. Cambridge: Cambridge UP, 1985. Print.

Botting, Arthur. "The Living Theatre." The Theatre of Protest in America.

Ed. Gary Norman and Arthur Botting. Edmonton: Harden, 1972. 18-19. Print.

Bottoms, Stephen J. Playing Underground: A Critical History of the 1960s Off-Off-Broadway Movement. Ann Arbor: U of Michigan P, 2006. Print.

Braun, Kazimierz. Krótka historia teatru amerykańskiego. Poznań: Wydawnictwo Naukowe UAM, 2005. Print.

Caines, Rebecca, and Ajay Heble. The Improvisation Studies Reader: Spontaneous Acts. Abingdon: Routledge, 2014. Print.

Coleman, Janet. The Compass: The Story of the Improvisational Theatre that Revolutionized the Art of Comedy in America. New York: Alfred A. Knopf, 1990. Print.

"Environmental Theatre." Britannica.com. Encyclopædia Britannica. Web. 10 Mar. 2018.

"Fluxus, Performance, Participation." Tate.org.uk. Tate Online. Web. 5 Aug. 2018.

Johnstone, Keith. Impro for Storytellers. New York: Routledge/Theatre Arts Books, 1999. Print.

Jotterand, Franck. Nowy teatr amerykański. Trans. Zofia and Kazimierz Braun. Warszawa: Wydawnictwa Artystyczne i Filmowe, 1976. Print.

Knizak, Milan. "Cover." The Fluxus Performance Workbook. Ed. Ken Friedman, Owen Smith, and Lauren Sawchyn. Digital supplement to Performance Research 7.3 (Sept. 2002). Academia.edu. Web. 5 Aug 2018.

“Lenny Bruce.” Bbc.co.uk. BBC Music Online. Web. 5 Aug. 2018.

"Living Theatre Records." Beineckelibrary.yale.edu. Yale University Library ca. 1947-2012. Web. 5 Aug. 2018. 
Mueller, Roswitha. Valie Export: Fragments of the Imagination. N.p.: Indiana UP, 1994. Print.

Napier, Mick. Improvise: Scene from the Inside Out. Portsmouth, NH: Heinemann, 2004. Print.

Olson, Stuart James. Historical Dictionary of the 1960s. Westport, CT: Greenwood, 1999. Print.

Regan, Sheila. "Dudley Riggs talks about Brave New Workshop Early Days." Tcdailyplanet.net. Twin Cities Daily Planet 2012. Web. 3 Mar. 2018.

Roose-Evans, James. Experimental Theatre. New York: Universe, 1970. Print.

Ross, Alex. The Rest Is Noise: Listening to the Twentieth Century. New York: Picador/Farrar, Straus and Giroux, 2007. Print.

"The San Francisco Mime Troupe, History." Sfmt.org. The San Francisco Mime Troupe. Web. 20 Apr. 2018.

Schumann, Peter. "Bread and Puppets." TDR: The Drama Review 12.2 (Winter 1968): 35. Print.

Secor, James L. "Bread and Puppet Theater." Encyclopedia of Activism and Social Justice. Ed. Gary L. Anderson and Kathryn G. Herr. Thousand Oaks: SAGE, 2007. 267-69. Print.

Sharma, Raja. Comedy in New Light-Literary Studies. N.p.: Lulu.com, 2011. Print.

Styan, J. L. Modern Drama in Theory and Practice: Symbolism, Surrealism and the Absurd. Volume 2. Cambridge: Cambridge UP, 1994. Print.

Szuster, Magdalena. "Alchemy and Smoke in a Bottle-Contemporary Improvisational Theater in Poland and the United States." Acta Universitatis Lodziensis: Folia Litteraria Polonica 2.40 (2017): 107-38. Print.

Tytell, John. The Living Theatre: Art, Exile, and Outrage. New York: Grove, 1997. Print.

---. "Troubadours Against Oppression. The Living Theatre: Art, Exile and Outrage." Articles.latimes.com. Los Angeles Times 9 Apr. 1995. Web. 5 Aug. 2018.

Witcover, Walt. My Road, Less Traveled: Becoming an Actor, a Director, a Teacher. N.p.: Xlibris, 2011. Print.

Magdalena SZUSter is affiliated with the Department of American Literature and Culture, Institute of English Studies, University of Łódź. She specializes in American theater and drama, and works now in the area of stage adaptations of plays by North American playwrights in Poland. Her most recent work on the production of The Crucible in the 
Stefan Jaracz Theater in Łódź was published in The Arthur Miller Journal 1.14 (2019). She is a member of the American Theatre and Drama Society. Since 2014, she has been collaborating with the Music Theater of Łódź. magda.szuster@gmail.com 